\section{Nyfødte er ikke bittesmå voksne}

\author{
Forskjeller i glukosemetabolisme mellom voksne og nyfødte kan gjøre \\ den nyfødte hjernen ekstra sårbar for oksidativt stress og eksitotoksisitet.
}

Hypoksisk-iskemiske episoder under svangerskap, fødsel og i neonatalperioden spiller en sentral rolle i utviklingen av hjerneskade hos nyfødte. Oksidativt stress og overstimulering av glutamatreseptorer (eksitotoksisitet) fører til celledød. Ved å metabolisere glukose gjennom pentose-fosfat-shunten kan cellene regenerere antioksidanter for å beskytte seg mot oksygenradikaler. Astrocyttene danner nytt glutamat fra glukose og har hovedansvaret for å ta opp glutamat etter frisetting fra nevronene. I voksne dyremodeller fører hypoksiske/iskemiske episoder til at pentose-fosfat-shunten oppreguleres og nydanning av glutamat reduseres.

Jeg har studert pentose-fosfat-shunten og glutamatsyntese i neonatale rotter utsatt for hypoksisk-iskemisk hjerneskade. Vi fant at hos nyfødte overføres det lite glutamat fra nevroner til astrocytter. Dette kan bety at astrocyttene har lavt glutamatopptak. Dessuten lager astrocyttene nytt glutamat etter en hypoksisk-iskemisk episode. Kombinasjonen kan gjøre den nyfødte hjernen spesielt utsatt for eksitotoksisitet. Pentosefosfat-shunten er i utgangspunktet mer aktiv hos nyfødte, men etter en hypoksisk-iskemisk episode blir den kraftig nedregulert, noe som kan innebære et dårligere forsvar mot oksygenradikaler enn hos voksne rotter.

Hvis liknende forskjeller finnes mellom nyfødte og voksne mennesker, kan det bety at det er mer å hente hos nyfødte enn hos voksne ved å redusere oksidativt stress og glutamateksitotoksisitet $\mathrm{i}$ forbindelse med hypoksisk-iskemisk hjerneskade.

Eva Brekke

eva.brekke@gmail.com

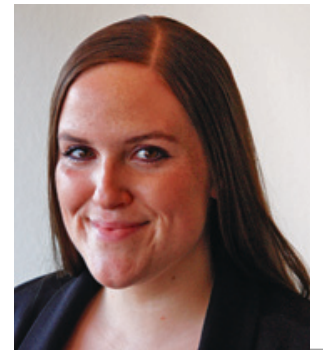

Eva Brekke. Foto: Privat

\section{Disputas}

Eva Brekke disputerte for ph.d.-graden ved Norges teknisk-naturvitenskapelige universitet den 31.1. 2014. Tittelen på avhandlingen er Aspects of glucose metabolism in vitro, in the healthy developing brain and after neontal hypoxia-ischemia. With particular focus on the pentose phosphate pathway and pyruvate carboxylation.

\title{
Hjernens mekanismer for stedskoding
}

\section{Steder kodes i hjernen ved at ulike grupper av nerveceller representerer retning, landemerker og koordinater. Informasjonen prosesseres gjen- nom et dynamisk samspill mellom disse cellegruppene.}

Det er mye vi ikke vet om hvordan høyere hjernefunksjoner foregår i nevrale nettverk. Stedsansen er blant de kognitive funksjonene som er best forstått, ettersom vi kan sammenlikne hjernesignalene med endringer i posisjon og omgivelser og dermed studere hva signalene betyr. Gittercellen i entorhinal cortex, som ble oppdaget av Moser-gruppen/Norges teknisk-naturvitenskapelige universitet i 2005, åpnet et vindu for å studere disse funksjonene nærmere.

Gittercellen lager et koordinatsystem for miljøet vi beveger oss i. Vi oppdaget at gittercellene er avhengig av aktivering fra stedsceller i hippocampus for å lage sine karakteristiske gitre, noe som støtter en ny matematisk modell for hvordan gittermønsteret oppstår. Videre avdekket vi prinsipper for hvordan retnings- og stedssignaler orga- niseres i entorhinal cortex. Vi fant også at gittercellene koder signalene sine i en spesiell relasjon til hjernerytmen theta, og at informasjonsflyten mellom cellegrupper kan styres gjennom frekvensregulering av gammarytmen.

Våre funn har avdekket nye aspekter ved organisering og prosessering av informasjon i hippocampus-entorhinal-systemet, prinsipper som kan være generelle for hvordan informasjon kodes og integreres i hjernen. Videre er funnene relevante for å forstå sykdommer som er relatert til hjerneområdene og funksjonene vi har studert, blant annet Alzheimers sykdom og schizofreni.

\section{Tora Bonnevie}

tora.bonnevie@ntnu.no

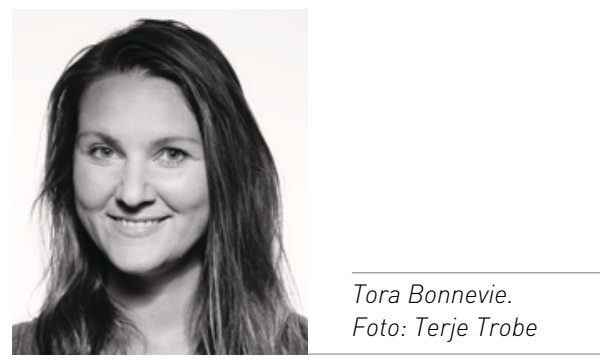

Disputas

Tora Bonnevie disputerte for ph.d.-graden ved Norges teknisk-naturvitenskapelige universitet 19.2. 2014. Tittelen på avhandlingen er Spatial representation in the brain - hippocampal impact on entorhinal grid cells. 